\title{
Duration of the Sypmtoms Influence the Outcome after Botulinum Toxin Injection in Anal Fissure
}

\section{Anal Fissürde Semptom Süresinin Botulinum Toksini Uygulaması Sonrası Sonuçlara Etkisi}

\author{
(1) Naciye Çiğdem Arslan, (1) Yaşar Özdenkaya \\ İstanbul Medipol University Faculty of Medicine, Department of General Surgery, İstanbul, Turkey
}

\section{HIIIII| ABSTRACT}

Aim: To assess the effect of duration of the symptoms on outcome after botulinum toxin injection in anal fissure treatment.

Method: Data of the patients who underwent botulinum toxin injection for chronic anal fissur were reviewed. Patients with a minimum follow-up of 18 months were included. One-hundred IU botulinum toxine was injected in the internal anal sphincter through 4 quadrants. Follow-up was carried out by clinic visits on post-procedure days 7,15 and 30 and by telephone survey in 3, 6, 12 and $18^{\text {th }}$ months. Refractory symptoms or recurrence were recorded as failure. The relationship between duration of the symptoms and failure was investigated and a cut-off value was determined. Patients were divided into two groups according to duration of the symtoms and outcome was compared with the patients who underwent lateral internal sphincterotomy within the same period.

Results: There were 56 patients fulfilling inclusion criteria. Mean age was $33.1 \pm 9.4$ and 39 (69.6\%) patients were female. Presence of the symptoms longer than 8.5 months was predicting treatment failure (Area under curve: 0.721, confidence interval: 0.500-0.942, p=0.037). There were 38 patients in shorter symptoms group, 18 patients in longer sypmtoms group and 32 patients in lateral internal sphincterotomy group. The compelte healing rates after 21 (18-28) months of median survival were 61.1\% in longer symptom botulinum toxin group, $94.7 \%$ in shorter symptom botulinum toxin group and $96.2 \%$ in lateral internal sphincterotomy group ( $\mathrm{p}=0.003$ ). One patient in botulinum toxin groups had local hematoma and one ( $3.1 \%$ ) had minor incontinence in lateral internal sphincterotomy group.

Conclusion: Botulinum toxin has similar outcome with lateral internal sphincterotomy in patients with shorter suration of sypmtoms. Proper patient selection may contribute to the success of the treatment in chronic anal fissur.

Keywords: Botulinum toxin, anal fissure, lateral internal sphincterotomy

\section{|||||||||| ÖZ}

Amaç: Anal fissürde semptom süresinin botulinum toksini uygulaması sonrası tedaviye yanıtsızlık ve nüks üzerindeki etkisini araştırmaktır. Yöntem: Mart 2016'dan itibaren anal fissür nedeniyle botulinum toksini uygulanan hastaların verileri incelendi. Takip süresi en az 18 ay olan hastalar çalışmaya dahil edildi. Hastalara internal sfinktere 4 kadrandan 100 IU botulinum toksin-A uygulandı. İşlem sonrası 7, 15, 30. günlerde poliklinik kontrolü ile; 3, 6, 12 ve 18. aylarda telefonla aranarak değerlendirme yapıldı. Botulinum toksini uygulamasına yanıtsızlık ya da nüks başarısızlık olarak kaydedildi. Semptom süresi ve başarısızlık arasındaki ilişki alıcı işletim karakteristiği analizi ile araştırıldı ve bulunan kesme değerine göre iki gruba ayrılan botulinum toksini uygulanan hastalar aynı dönemde lateral internal sfinkterotomi ile tedavi edilmiş hastalarla karşılaştırıldı.

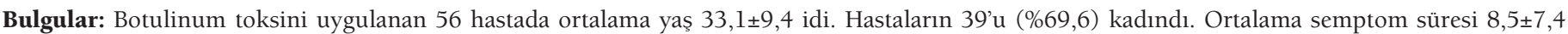
aydı. Ortanca 21 (18-28) aylık izlem süresinde $47(\% 83,9)$ hastada iyileşme oldu. Semptom süresinin 8,5 aydan uzun olması tedavi başarısızlı̆̆ını öngörmekteydi (Eğri altındaki alan: 0,721, güven aralığı: 0,500-0,942, p=0,037). Hastalar semptom süresine göre 2 gruba ayrılarak aynı dönemde lateral internal sfinkterotomi yapılan 32 hasta ile sonuçları karşılaştırıldı. İyileşme oranları semptom süresi uzun olan botulinum toksini grubunda $\% 61,1$, semptom süresi kısa olan botulinum toksini grubunda \%94,7 ve lateral internal sfinkterotomi grubunda \%96,2 idi ( $\mathrm{p}=0,003$ ). Botulinum toksini uygulaması sonrası 1 hastada lokal hematom, lateral internal sfinkterotomi uygulaması sonrası 1 (\%3,1) hastada minör inkontinens görüldü. Sonuç: Anal fissür tedavisinde botulinum toksini uygulaması semptom süresi kısa olan hastalarda lateral internal sfinkterotomi ile benzer etkinliktedir. Botulinum toksini uygulamasında hasta seçimi tedavi başarısını etkileyebilir.

Anahtar Kelimeler: Botulinum toksini, anal fissür, lateral internal sfinkterotomi 


\section{Introduction}

Anal fissure (AF) is a painful tear extending from the anal canal to the dentate line. Although the exact pathophysiology is not known, an increase in anal tonus, decreased anodermal blood flow and local ischemia are possible mechanism. ${ }^{1}$ Most patients have various degrees of constipation and defecation problems. These patients are in a vicious circle where pain, increased anal tonus and demanding excretion trigger each other. This cycle results in chronic inflammation and ischemic ulcers that do not heal. Symptoms lasting longer than 8 weeks are defined as chronic AF. ${ }^{2}$ In chronic AF, usually internal sphincter fibers appear in the anal canal. Hypertrophic anal papillae and skin tag may accompany.

Topical nitrates and calcium channel blockers relieve the symptoms in more than half of the patients, but up to 50\% recurrence rates and side effects limit the use of topical treatments in chronic AF. ${ }^{3,4}$ The most effective treatment modality in chronic AF is lateral internal sfinkterotomy (LIS) and it is recommended to use it as the first step without waiting for failure with topical treatments in selected patients. ${ }^{2}$ In many randomized controlled trials, recovery rates after LIS have been shown to be higher and recurrence is lower than topical nitrate, calcium channel blockers and botulinum toxin (BT) treatments. ${ }^{5,6,7}$ However, post-LIS incontinence rates are still reported as high as $8-30 \%{ }^{8,9}$

BT is a reliable and effective method for treating AF with similar healing rates and a lower side effect profile compared to topical treatments. ${ }^{10,11,12}$ Lack of persistent side effects, easy applicability and reproducibility have brought BT as an alternative to LIS. The American Society for Colorectal Surgeons (ASCRS) 2017 reported that BT and topical treatments were equally effective at the first step in the treatment of chronic AF. ${ }^{2}$ In a new meta-analysis, the effectiveness of LIS was emphasized, but it was proposed to take into account the risk-benefit analysis in the choice of treatment because of the high rates of postoperative complications. ${ }^{13}$

In chronic AF treatment, there are still no guidelines on which treatment is most effective and reliable, and there are no widely accepted guidelines in the treatment of chronic AF. In clinical practice, there is a tendency to prefer LIS instead of conservative treatments. Failure and costs can be reduced after treatment if it is determined which patients can benefit from less invasive methods such as BT; complications of surgical treatment can be avoided. In our study, we aimed to investigate the effect of symptom duration on outcome with hypothesis that patients with shorter symptom duration may have more benefit with BT treatment.

\section{Materials and Methods}

The study was approved by the ethics committee of the university. All patients were informed in detail about the outcomes and complications of treatment options and written informed consent was obtained from the patients for both interventions and using their data in the study. The authors' first step approach in acute AF is 8-week-old topical diltiazem oinment, abundant fiber diet, stool softeners and hot water sitting bath. Patients with complaints longer than 8 weeks were evaluated as chronic AF regardless of previous history of topical treatment. BT or LIS was recommended for the first-line treatment. Age, sex, fertility, continence, socio-economic conditions and patient wish were evaluated and treatment method was decided. The authors started to use BT in clinical practice since 2016, therefore, data of the patients who were assessed for AF after 2016 were reviewed retrospectively for the study. Patients who underwent BT or LIS due to chronic AF and had a follow-up of at least 18 months were included in the study. Patients with inflammatory bowel disease, malignancy, previous anorectal surgery and other accompanying perianal disease (anal fistula, hemorrhoids, etc.) were excluded from the study.

All patients were diagnosed with AF by history and rectal digital examination. Over eight weeks of complaints accompanying ulcers or tears of anal canal were evaluated as chronic AF. Presence of hypertrophic papilla and/or skin tag was recorded. The anal tonus was recorded as low, normal and high by the surgeon as the subject during rectal examination. The results of anal manometric examination were not used in the study because manometry could not be applied in every patient for economic reasons. The diagnosis of chronic constipation was made according to Rome IV criteria. $^{14}$

\section{Application of Botulinum Toxin}

The procedures were performed at outpatient clinic without anesthesia except for one patient who received general anesthesia. Lyophilized 100 IU BT Type-A (BOTOX, Alergan, CA, USA) was applied after diluated with $1 \mathrm{cc}$ saline and 26-G injector was used to inject 25 unit toxin in 4 quadrants, to the alignment of clock 12, 3, 6 and 9 to internal anal sphincters.

\section{Lateral Internal Sphincterotomy}

The operations were performed in the operating room under spinal anesthesi on her own will. In the lithotomy position, the internal sphincter was divided by electrocautery from the incision made at 3 o'clock position. The wound was left open. The patients were discharged on the same day after surgery. 


\section{Follow up}

All patients were examined at the outpatient clinic on the $7^{\text {th }}$, $15^{\text {th }}$ and $30^{\text {th }}$ days. Complications, fissure epithelization and complications were evaluated. Cleveland Clinic Incontinence Score was used in the diagnosis of incontinence. ${ }^{15}$ The patients who had complete healing after first 30 days were not routinely followed at clinic visits anymore. They were advised to apply to our department if any complaints occur. All patients were inquired at the $3^{\text {rd }}, 6^{\text {th }}, 12^{\text {th }}$ and $18^{\text {th }}$ months by telephone. The patients who had complaints at telephone survey were invited for the examination. Complete recovery of symptoms and epithelialization in the fissure was defined as complete healing. Regardless of the fissure epithelization, if pain or bleeding has still existed on postoperative $30^{\text {th }}$ day, the patients was counted in noresponse group. Relaps of the symptoms after complete healing was defined as recurrence. Patients with no-response and recurrence were included in 'tratment failure' group. In case of treatment failure, readministration of BT or LIS was recommended to the patients.

\section{Study Groups}

The cut-off value of symptom duration to be determined for the success of BT administration was calculated and patients were divided into two groups according to the duration of symptoms. The results of the patients with short and long duration of the symptoms were compared with those underwent LIS during the same period.

\section{Statistical Analysis}

The analyzes were performed with SPSS 21 program. Variables were expressed as mean and standard deviation. Chi-square test was used for comparisons between categorical variables, and independent samples t-test was used for comparisons between continuous variables. The cut-off values of the factors predicting treatment failure were determined by ROC analysis.

\section{Results}

Between March 2016 and July 2018, 117 patients underwent a BT due to AF by a single surgeon. 38 patients with a follow-up of less than 18 months were excluded from the study. 13 patients due to other accompanying perianal disease, 4 patients due to previous anorectal surgery, 2 patients due to inflammatory bowel disease and 1 patient due to malignancy were excluded from the study. Three patients could not be reached after 3-month controls. A total of 56 patients were included in the study. The mean age was 33.1 \pm 9.4 (range, 18-57), 39 (69.6\%) were female and $17(30.4 \%)$ were male. Mean duration of symptoms was $8.5 \pm 7.4$ months (range, 2 to 36 months), and duration of constipaion was $18.9 \pm 34$ months (range, 2 to 200). Of the patients, 35 (62.5\%) had chronic constipation. In 11 (28.2\%) female patients, onset of symptoms was associated with pregnancy or delivery. Detailed demographic and clinical features are given in Table 1. After the first 30 days, $53(94.6 \%)$ patients had complete recovery. Three (5.4\%) patients had no-response to treatment. One of them was reintroduced to BT, two of them underwent LIS and all had complete recovery. Recurrence was observed at the $5^{\text {th }}$ month in a patient who underwent BT for the second time.

Table 1. Demographic and clinical characteristics of patients

\begin{tabular}{ll} 
& $\mathbf{n}(\%)$ \\
Age (year, mean \pm SD) & $33.1 \pm 9.4$ \\
Sex & \\
Female & $39(69.6)$ \\
Male & $17(30.4)$ \\
Duration of the symptoms (month, mean \pm SD) & $8.5 \pm 7.4$ \\
Duration of constipation (month, mean \pm SD) & $18.9 \pm 34$ \\
Chronic constipation & \\
No & $22(33.8)$ \\
Yes & $42(66.2)$ \\
Previous medical treatment & $11(19.6)$ \\
No & $45(80.4)$ \\
Yes & \\
Fissure site & $50(89.3)$ \\
Posterior & $4(7.1)$ \\
Anterior & $2(3.6)$ \\
Multiple & \\
\hline
\end{tabular}

Skin tag/anal papilla

No

$25(44.6)$

Yes

$31(55.4)$

Anal tonus

Normal

$13(23.2)$

High

$43(76.8)$

Relationship with pregnancy/childbirth

No

Yes

$11(28.2)$

Result

Complete healing

$47(83.9)$

No-response

$3(5.4)$

Recurrence

$6(10.7)$

Time to recurrence (months, mean \pm SD)

$7.3 \pm 1.9$

SD: Standard deviation 
Table 2. Subgroup analysis of the patients regarding duration of the sypmtoms and comparison of the subgroups with lateral internal sphincterotomy group

\begin{tabular}{|c|c|c|c|c|}
\hline & & $1=56)$ & LIS $(n=32)$ & $\mathrm{p}$ \\
\hline & $<8.5$ months $(\mathrm{n}=38)$ & $\geq 8.5$ months $(\mathrm{n}=18)$ & & \\
\hline Age $($ year, mean $\pm S D)$ & $33.2 \pm 9.3$ & $32.7 \pm 10.2$ & $30 \pm 9.1$ & 0.151 \\
\hline Sex & & & & 0.318 \\
\hline Female & 28 & 11 & 21 & \\
\hline Male & 10 & 7 & 11 & \\
\hline Result & & & & 0.003 \\
\hline Complete healing & $36(94.7 \%)$ & $11(61.1 \%)$ & $31(96.2 \%)$ & \\
\hline No-response & - & $3(16.6 \%)$ & - & \\
\hline Recurrence & $2(5.3 \%)$ & $4(22.2 \%)$ & $1(3.1 \%)$ & \\
\hline
\end{tabular}

SD: Standard deviation, BT: Botulinum toxin, LIS: Lateral internal sphincterotomy

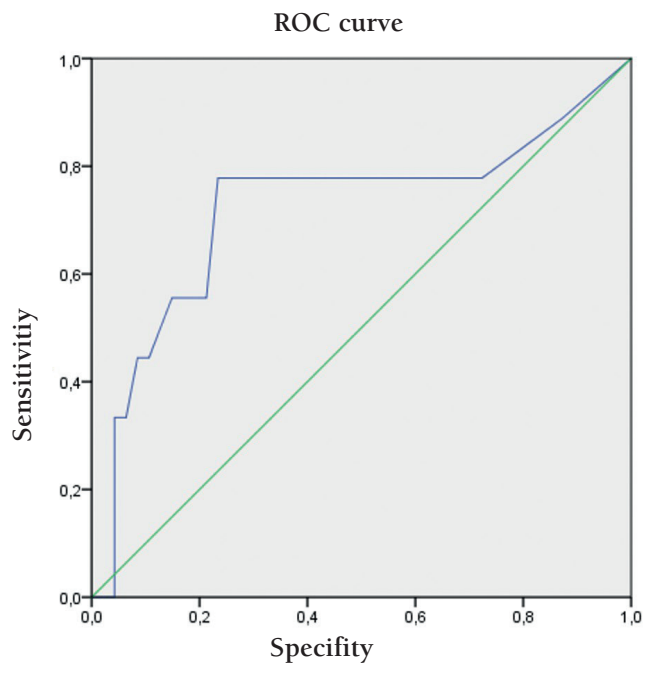

Figure 1. Receiver operative characteristic curve for duration of the symptoms (area under curve: 0.721, confidence interval: 0.500-0.942, $\mathrm{p}=0.037$ )

These three patients were evaluated in the tratment failure group. In the follow-up, 6 patients relapse AF in a mean of $7.3 \pm 1.9$ months. All patients underwent complete recovery after LIS. No incontinence was observed in any patient. In one $(1.7 \%)$ patient, local hematoma developed in the anal region and spontaneously regressed within 1 week.

After median 21 (18-28) months, 47 (83.9\%) patients had complete recovery. Three patients with no-response and 6 with recurrence, $16.1 \%$ of the patients were recorded as treatment failure. The mean symptom duration was $7.5 \pm 6.68$ months in patients with successful treatment, and $13.8 \pm 8.9$ months in patients who failed treatment $(\mathrm{p}=0.017)$. The symptom duration longer than 8.5 months predicted treatment failure with $78 \%$ sensitivity and $77 \%$ specificity.
The data of 51 patients who underwent LIS due to chronic AF during the same period with BT patients were analyzed. Thirteen patients did not complete 18-month follow-up period, 5 patients with concomitant perianal disease, and 1 had previous hemorrhoidectomy were excluded from the study. Patients treated with BT were grouped according to the 8.5 month cut-off value and compared to 32 patients who underwent LIS and met the inclusion criteria. The complete healing rate in BT patients was $61.1 \%$ in $\geq 8.5$ months group and $94.7 \%$ in $<8.5$ months group ( $\mathrm{p}=0.003$ ). In LIS group, complete healing was observed in $96.2 \%$ of the patients. There was no difference in complete healing rate between $<8.5$ months BT group and LIS group ( $>>0.005)$ (Table 2). One $(3.1 \%)$ of patients in the LIS group developed minor incontinence (Cleveland Clinic Incontinence Score: 4).

\section{Discussion}

The most effective method in AF treatment is LIS. Although LIS is a day-case procedure, it's performed under general or spinal anesthesia. Although less important complications such as pain, hemorrhage, perianalsepsis, and hematoma other than incontinence have not been well studied in the literature, they can be quite painful in clinical practice. Therefore, less interventional therapies have always been the focus of attention in the treatment of AF. Medical treatment options of topical calcium channel blockers and nitrates do not provide satisfactory long-term results. ${ }^{3,4}$ Low adherence to these treatments and headache caused by nitrates were also associated with failure. ${ }^{16}$ Today, medical treatment is the first choice only in the treatment of acute AF. ${ }^{2}$

Botulinum toxin, which causes temporary paralysis in the internal anal sphincter, is a less invasive and safe alternative 
to LIS. There is no widely accepted dose and injection points in the clinical practice. In two meta-analyzes published in 2016, it was concluded that BT did not have a dose-dependent effect in terms of recovery, incontinence, and recurrence, but the studies were very heterogeneous and the follow-up period was short. ${ }^{17,18}$ There was no difference between the injection points in both meta-analyzes. In a recent study with a median follow-up of 25 months, high-dose (80-100 IU) and low dose (20-40 IU) BT were compared and high dose BT was found to be superior to low dose in terms of patient satisfaction ( $90 \%$ vs $78 \%, \mathrm{p}=0.05$ ) and recurrence ( $23 \%$ vs $53 \%, p=0.0001$ ). Long-term incontinence was not reported in either group. In our study, 100 IU BT was applied to all patients and incontinence was not observed.

In a meta-analysis of 6 studies including 393 patients, treatment response was reported as $28.6 \%$ for BT and $42.1 \%$ for nitrates ( $\mathrm{p}=0.24) .{ }^{12}$ In our study, the rate of non-response to treatment was $5.4 \%$ and increased to $16.6 \%$ in patients with complaints longer than 8.5 months. In the same metaanalysis, recurrence after BT and nitrate was $18.5 \%$ and $25.1 \%(\mathrm{p}=0.22)$. While transient incontinence was higher with BT $(10.4 \%)$ compared to nitrates $(4.4 \%)(\mathrm{p}=0.06)$, BT was found to be superior to nitrates regarding overall sideeffects ( $33 \%$ vs $6.4 \%, \mathrm{p}=0.01$ ). Topical treatment duration, BT doses and follow-up periods were very heterogeneous, and the definitons of chronic AF and complete healing were conflicting in this meta-analysis. These result indicate the clinical conflictions in AF treatment.

In another meta-analysis, 44 randomized controlled trials involving 3268 patients with anal dilatation, LIS, anoplasty and/or fissurectomy, BT, and topical therapies were reviewed. ${ }^{13}$ The median follow-up was 2 years, and complete healing rates were $25-96 \%$ and $38-100 \%$ for BT and LIS. Incontinence rates were $0-10 \%$ for BT and $0-44 \%$ for LIS. In our study, incontinence did not develop after BT and minor incontinence occurred in 1 (3.1\%) patient who underwent LIS. In this meta-analysis, failure rates after BT were 0-78\%. In our patients, the failure rate after BT was $16 \%$. This rate decreases to $5.3 \%$, which is comparable with LIS (3.1\%) in patients with shorter duration of symptoms.

There is no widely accepted patient selection criteria and algorithms for BT which has been increasingly preferred as the first-line therapy for chronic AF. Clinicians usually determine the treatment options individually by considering benefit-risk analysis. Although there is no evidence to support this view in the literature, we think that surgical treatment will result in better long-term satisfaction in patients with long symptom duration and chronic constipation. Theoretically, if the factors associated with sphincter spasm and anal trauma persist after the BT effect has vanished, the relapse of the disease will be easier. We believe that this possibility is higher in patients with longterm symptoms.

Determination of risk factors for no-response or recurrence after BT may provide better selection of the patients who are going to have more benefit from BT. In the literature, there are a few studies investigating factors related with recurrence after BT application. ${ }^{19,20}$ These studies revealed that persisting pain after 30 days and the lack of high anal tone were associated with recurrence. In a randomized controlled trial of 99 patients in Iran in 2015, the results of LIS and topical diltiazem + BT were compared. ${ }^{21}$ At the end of one-year follow-up, healing rates were $65 \%$ in BT + diltiazem group and 94\% in LIS group. Complete healing rates for both BT and LIS were reported to be $100 \%$ in patients with a symptom duration of less than 12 months. The complete recovery rate of LIS and BT + diltiazem was $86 \%$ and $23 \%$ in patients with symptom duration longer than 12 months $(\mathrm{p}<0.001)$. Differently from this study, we fund a cut-off value associated with treatment failure and showed that patients with $<8.5$ months of symptoms had more benefit from BT. In our study, no topical treatment was performed with BT or LIS.

\section{Study Limitations}

The major limitations of our study are the retrospective design and small number of patients. Subgroup analysis according to the duration of symptoms in LIS group was not performed because of small number and lack of data. Our follow-up period is sufficient considering that most of the previous studies has reported 12 months or shorter terms results.

Anal BT is a minimally invasive, safe and effective treatment. Complete healing rates are high, however no-response and recurrence rates are still unsatisfactory when compared to LIS. In patients with shorter symptoms, outcome of BT can be better. Randomized trials should be performed to determine the criteria for $\mathrm{BT}$ treatment in AF.

\section{Ethics}

Ethics Committee Approval: The study was approved by the İstanbul Medipol University Ethics Committee (approval number: 10840098-604.01.01-E.45124).

Informed Consent: Written informed consent was obtained from the patients.

Peer-review: Externally peer-reviewed.

\section{Authorship Contributions}

Surgical and Medical Practices: N.Ç.A., Concept: N.Ç.A., Y.Ö., Design: N.Ç.A., Y.Ö., Data Collection or Processing: N.Ç.A., Y.Ö., Analysis or Interpretation: Y.Ö., N.Ç.A., Literature Search: Y.Ö., Writing: N.Ç.A., Y.Ö. 


\section{Conflict of Interest: No conflict of interest was declared by} the authors.

Financial Disclosure: The authors declared that this study received no financial support.

\section{References}

1. Schouten WR, Briel JW, Auwerda JJA, De Graaf EJR. Ischaemic nature of anal fissure. Br J Surg 1996;83:63-65.

2. Stewart DB, Gaertner W, Glasgow S, Migaly J, Feingold D, Steele SR. Clinical Practice Guideline for the Management of Anal Fissures. Dis Colon Rectum 2017;60:7-14.

3. Berry SM, Barish CF, Bhandari R, Clark G, Collins GV, Howell J, Pappas JE, Riff DS, Safdi M, Yellowlees A. Nitroglycerin $0.4 \%$ ointment vs placebo in the treatment of pain resulting from chronic anal fissure: A randomized, double-blind, placebo-controlled study. BMC Gastroenterol 2013;13:106.

4. Pardhan A, Azami R, Mazahir S, Murtaza G. Diltiazem vs. Glyceryl trinitrate for symptomatic relief in anal fissure: A randomised clnical study. J Pak Med Assoc 2014:64:510-513.

5. Arroyo A, Pérez F, Serrano P, Candela F, Lacueva J, Calpena R. Surgical versus chemical (botulinum toxin) sphincterotomy for chronic anal fissure: Long-term results of a prospective randomized clinical and manometric study. Am J Surg 2005. doi:10.1016/j.amjsurg.2004.06.045.

6. Katsinelos P, Papaziogas B, Koutelidakis I, Paroutoglou G, Dimiropoulos S, Souparis A, Atmatzidis K. Topical 0.5\% nifedipine vs. lateral internal sphincterotomy for the treatment of chronic anal fissure: Long-term followup. Int J Colorectal Dis 2006;21:179-183.

7. Brown CJ, Dubreuil D, Santoro L, Liu M, O'Connor BI, McLeod RS. Lateral internal sphincterotomy is superior to topical nitroglycerin for healing chronic anal fissure and does not compromise long-term fecal continence: Six-year follow-up of a multicenter, randomized, controlled trial. Dis Colon Rectum 2007;50:442-448.

8. Hyman N. Incontinence after Lateral Internal Sphincterotomy: A Prospective Study and Quality of Life Assessment. Dis Colon Rectum 2004:47:35-38.

9. Menteş BB, Irkörücü O, Akin M, Leventoğlu S, Tatlicioğlu E. Comparison of botulinum toxin injection and lateral internal sphincterotomy for the treatment of chronic anal fissure. Dis Colon Rectum 2003;46:232-237.
10. Berkel AEM, Rosman C, Koop R, van Duijvendijk P, van der Palen J, Klaase JM. Isosorbide dinitrate ointment vs botulinum toxin A (Dysport) as the primary treatment for chronic anal fissure: a randomized multicentre study. Colorectal Dis 2014;16:360-366.

11. Sajid MS, Vijaynagar B, Desai M, Cheek E, Baig MK. Botulinum toxin vs glyceryltrinitrate for the medical management of chronic anal fissure: a meta-analysis. Colorectal Dis 2008; 10:541-546.

12. Sahebally SM, Meshkat B, Walsh SR, Beddy D. Botulinum toxin injection vs topical nitrates for chronic anal fissure: an updated systematic review and meta-analysis of randomized controlled trials. Color Dis 2018;20:6-15.

13. Ebinger SM, Hardt J, Warschkow R, Schmied BM, Herold A, Post S, Marti L. Operative and medical treatment of chronic anal fissures-a review and network meta-analysis of randomized controlled trials. J Gastroenterol 2017;52:663-676

14. Lacy BE, Mearin F, Chang L, Chey WD, Lembo AJ, Simren M, Spiller R. Bowel disorders. Gastroenterolog 2016;150:126-134.

15. Rockwood TH, Church JM, Fleshman JW, Kane RL, Mavrantonis C, Thorson AG, Wexner SD, Bliss D, Lowry AC. Patient and surgeon ranking of the severity of symptoms associated with fecal incontinence: the fecal incontinence severity index. Dis Colon Rectum 1999;42:1525-1532.

16. Nelson RL, Thomas K, Morgan J, Jones A. Non surgical therapy for anal fissure. Cochrane Database Syst Rev 2012;CD003431.

17. Bobkiewicz A, Francuzik W, Krokowicz L, Studniarek A, Ledwosifski W, Paszkowski J, Drews M, Banasiewicz T. Botulinum Toxin Injection for Treatment of Chronic Anal Fissure: Is There Any Dose-Dependent Efficiency? A Meta-Analysis. World J Surg 2016;40:3064-3072.

18. Lin JX, Krishna S, Su'A B, Hill AG. Optimal Dosing of Botulinum Toxin for Treatment of Chronic Anal Fissure: A Systematic Review and MetaAnalysis. Dis Colon Rectum 2016;59:886-894.

19. Dat A, Chin M, Skinner S, Farmer Cl, Wale R, Carne P, Bell S, Warrier SK. Botulinum toxin therapy for chronic anal fissures: Where are we at currently? ANZ J Surg 2017;87:E70-E73.

20. Chan DL, Ravindran P, White SI. Anal tone may predict recurrence after botulinum toxin for chronic anal fissure. ANZ J Surg 2018;88:385-386.

21. Gandomkar H, Zeinoddini A, Heidari R, Amoli HA. Partial lateral internal sphincterotomy versus combined botulinum toxin A injection and topical diltiazem in the treatment of chronic anal fissure: A randomized clinical trial. Dis Colon Rectum 2015;58:228-234. 